\title{
LIPID ABNORMALITIES IN CHRONIC RENAL FAILURE ASSOCIATED WITH SPINAL CORD INJURY
}

\author{
By N. D. Vaziri, M.D., S. Gordon M.D., and B. Nikakhtar, M.D. \\ Division of Nephrology, University of California, Irvine, California and S.C.I. and \\ Medical Services, Long Beach Veterans Administration Medical Center, \\ Long Beach, California
}

\begin{abstract}
Serum lipid fractions were studied in ten patients with chronic renal failure (CRF) associated with long-standing spinal cord injury (SCI). A group of age-and-sexmatched patients with long-standing SCI but normal renal function were included for comparison. Serum triglycerides were markedly elevated in SCI-CRF patients. Both SCI groups exhibited moderate hypocholesterolemia. High density lipoprotein (HDL) cholesterol was severely reduced in the SCI-CRF group and moderately reduced in the SCI-control group. Chronic renal failure, reduced physical activity and several other factors may be operative in the genesis of hypertriglyceridemia and reduced HDLcholesterol levels in this condition. Further investigations are necessary to examine the possible effect of these lipid abnormalities on the cardiovascular system in these patients.
\end{abstract}

Key words: Spinal cord injury; Chronic renal failure; Hemodialysis; Lipid disorders.

\section{Introduction}

LIPID metabolism is abnormal and mortality from cardiovascular disease is increased in patients with chronic renal failure treated with dialysis or transplantation (Lindner et al., I974; Lowrie et al., I974; Bierman \& Brunzell, I978). Elevated serum triglycerides, normal or reduced total cholesterol, increased triglyceride-rich very low density lipoprotein (VLDL), increased high density lipoprotein (HDL)-triglycerides and reduced HDL-cholesterol have all been demonstrated in ambulatory dialysis patients (Lewis et al., I966; Bagdade et al., I968; Losowsky \& Kenward, I968; Brons et al., I972; Ibels et al., I975; Daubresse et al., I976; Bagdade et al., I976; Brunzell et al., I977; Bagdade et al., I977; Vaziri et al., I980). Long-term physical exercise programs have been shown to lower serum total triglycerides and VLDL-triglycerides and increase HDL-cholesterol in dialysis patients (Goldberg et al., 1979) as well as the nonuremic individuals (Holloszy et al., 1964; Lopez et al., I974; Gyntelberg et al., 1977; Erklens et al., I978).

Long-standing spinal cord injury (SCI) can cause chronic renal failure (CRF) due to the associated neuropathic bladder dysfunction, chronic pyelonephritis, urolithiasis and secondary amyloidosis. In addition to uremia, several other factors can potentially influence lipid metabolism in this setting. These include relative physical hypoactivity, possible systemic amyloidosis, peculiar nature of renal pathology and characteristics of residual renal function to mention a few. To our knowledge, data on lipid metabolism in CRF associated with SCI are lacking. Here we report our data on the subject.

This study was generously funded by the late Eldore G. Reinis.

Address for reprints: N. D. Vaziri, M.D., Medical Sciences I, Room C35I, Division of Nephrology, Department of Medicine, University of California, Irvine, California 927I 7 


\section{Patients and Methods}

Ten paraplegic men with advanced chronic renal failure aged $59 \pm \mathrm{I} 2$ years were studied (Table I). Patients with diabetes mellitus, hypothyroidism, discernible liver disease and alcoholism were excluded. Five of the ten patients had creatinine clearances between 4 and $8 \mathrm{ml} /$ minute and required maintenance hemodialysis. These patients received dialysis treatment for 4 hours, 2 to 3 times a week. A single-pass dialysate delivery system, a glucose-free acetate-based

TABLE I

Clinical Data

\begin{tabular}{|c|c|c|c|c|c|c|c|c|}
\hline Patients & $\begin{array}{r}\text { Age } \\
\text { (yrs.) }\end{array}$ & $\begin{array}{l}\text { Level } \\
\text { of SCI }\end{array}$ & $\begin{array}{l}\text { Duration } \\
\text { of SCI } \\
\text { (yrs.) }\end{array}$ & $\begin{array}{l}\text { Duration } \\
\text { dialysis } \\
\text { (months) }\end{array}$ & $\begin{array}{l}\text { Creatinine } \\
\text { clearance } \\
(\mathrm{ml} / \mathrm{min})\end{array}$ & $\begin{array}{l}\text { Serum } \\
\text { albumin } \\
\text { (g/dl) }\end{array}$ & $\begin{array}{l}\text { 24-hr Urine } \\
\text { protein } \\
\text { (g/day) }\end{array}$ & $\begin{array}{l}\text { Blood } \\
\text { pressure } \\
\text { (mmHg) }\end{array}$ \\
\hline I & $7 \mathrm{I}$ & $\mathrm{C}_{5}$ & 36 & 9 & $6 \cdot 0$ & $2 \cdot 3$ & $I \cdot O$ & I68/I IO \\
\hline 2 & 62 & T5 & 37 & 6 & $5 \cdot 0$ & $2 \cdot 7$ & $3 \cdot I$ & $125 / 65$ \\
\hline 3 & 69 & TI2 & 22 & 4 & $4 \cdot 0$ & $3 \cdot 2$ & $I \cdot O$ & I45/90 \\
\hline 4 & 57 & $\mathrm{C}_{5}-6$ & 23 & 3 & $6 \cdot 0$ & $2 \cdot 9$ & $2 \cdot I$ & $170 / 85$ \\
\hline 5 & 68 & $C_{5}-6$ & 28 & I8 & $4 \cdot 0$ & $3 \cdot 2$ & 0.7 & $135 / 70$ \\
\hline 6 & 57 & $\mathrm{C}_{4}-5$ & $2 \mathrm{I}$ & 一 & $10 \cdot 0$ & $3 \cdot I$ & I. 4 & I68/95 \\
\hline 7 & 46 & $\mathrm{C}_{5}$ & I8 & - & $22 \cdot 0$ & $3 \cdot 5$ & 0.4 & $120 / 75$ \\
\hline 8 & 60 & $\mathrm{C}_{5}-6$ & 34 & - & $12 \cdot 0$ & $3 \cdot 2$ & $I \cdot I$ & $185 / 80$ \\
\hline 9 & 32 & $\mathrm{C}_{5}$ & I3 & - & $17 \cdot 0$ & $3 \cdot 5$ & 0.6 & $165 / 85$ \\
\hline IO & 68 & $\mathrm{C}_{5}$ & 36 & - & $18 \cdot 0$ & 3.5 & 0.9 & $145 / 83$ \\
\hline
\end{tabular}

dialysate, and hollow fibre or parallel flow dialysers with $\mathrm{r} \cdot 2-2 \cdot 5 \mathrm{~m}$ surface areas ${ }^{2}$ were used. The remaining five patients had creatinine clearances ranging from Io to $22 \mathrm{ml} /$ minute and did not require dialysis. Dietary restrictions were limited to sodium, potassium and fluid intakes as needed to control fluid overload and hyperkalemia. No protein or caloric restrictions were imposed. Aluminium carbonate was prescribed to control hyperphosphatemia and multivitamin, folic acid, pyridoxine and oral or parenteral iron supplements were administered.

The etiology of chronic renal failure was presumed to be chronic pyelonephritis with or without amyloidosis. Urinary protein excretion ranged from 0.4 to $3 . \mathrm{Ig}$ /day. All patients had chronic pyuria and bacteriuria. They were free of acute illnesses and stress at the time of the study and for several weeks previously.

A control group of age- and sex-matched patients with spinal cord injury, but without significant renal failure (creatinine clearance $=86 \pm \mathrm{I} 4 \mathrm{ml} / \mathrm{min}$ ) were included for comparison. The lipid values from the SCI patients with and without renal failure were compared with those previously reported on normal population and hypertriglyceridemic individuals (Goldstein et al., I973; Albers et al., 1976).

Venous blood samples for lipid analyses were obtained following a I4-hour fasting period. In patients undergoing maintenance dialysis blood samples were drawn before the dialysis session which was preceded by the longest interdialytic interval (3 to 4 days). Serum cholesterol and triglyceride concentrations and HDLcholesterol were measured as previously described (Goldstein et al., 1973; Albers et al., 1976).

Linear regression and a $t$-test were used in statistical analysis of the data. All data are expressed as mean \pm standard deviation. 


\section{Results}

The results are displayed in Table II. Serum total triglyceride concentration in the SCI patients with chronic renal failure $(\mathrm{I} 80 \pm 96 \mathrm{mg} / \mathrm{dl})$ was significantly $(P<0.05)$ higher than the values obtained in the SCI patients without renal failure $(100 \pm 22 \mathrm{mg} / \mathrm{dl})$, and those previously reported in the age- and sex-matched normal individuals ( $104 \pm 4 \mathrm{mg} / \mathrm{dl} ; P<0.05)$. There was no significant difference in the serum triglyceride levels between the SCI patients without renal disease and their age- and sex-matched normal control individuals.

There was no significant difference in serum cholesterol between the SCI patients with renal failure $(152 \pm 56 \mathrm{mg} / \mathrm{dl})$ and SCI patients without renal failure $(\mathrm{I} 42 \pm \mathrm{I} 8 \mathrm{mg} / \mathrm{dl})$. However, serum cholesterol levels in both SCI groups were significantly lower than those established for their age- and sex-matched normal control individuals $(224 \pm \mathrm{I} 2 \mathrm{mg} / \mathrm{dl})$.

HDL-cholesterol was significantly $(P>0.00 I)$ lower in the SCI patients with renal failure $(12 \pm 8 \mathrm{mg} / \mathrm{dl})$ than that found in the SCI patients without renal failure $(3 \mathrm{I} \pm 9 \mathrm{mg} / \mathrm{dl})$. HDL-cholesterol levels in both SCI groups were significantly lower than those found in their age- and sex-matched normal control

\section{TABLE II}

Comparison of the lipid data in SCI patients with chronic renal failure, SCI patients without renal failure, and age- and sex-matched normal control group

\begin{tabular}{|c|c|c|c|}
\hline Patients & $\begin{array}{c}\text { Triglycerides } \\
\mathrm{mg} / \mathrm{dl}\end{array}$ & $\begin{array}{l}\text { Cholesterol } \\
\mathrm{mg} / \mathrm{dl}\end{array}$ & $\begin{array}{l}\text { HDL-Cholesterol } \\
\mathrm{mg} / \mathrm{dl}\end{array}$ \\
\hline I & 130 & I33 & $10 \cdot 0$ \\
\hline 2 & I74 & 164 & $3 I \cdot 5$ \\
\hline 3 & 164 & 163 & $8 \cdot 3$ \\
\hline 4 & 142 & 97 & $7 \cdot 5$ \\
\hline 5 & 162 & I 49 & 6.8 \\
\hline 6 & 73 & 69 & $7 \cdot 5$ \\
\hline 7 & 158 & 140 & II $\cdot 7$ \\
\hline 8 & 185 & 164 & $8 \cdot 0$ \\
\hline 9 & I67 & 158 & I8.0 \\
\hline IO & 440 & 284 & $83 \cdot 0$ \\
\hline Mean \pm SD & $180 \pm 96$ & I $52 \pm 56$ & $12 \pm 8$ \\
\hline SCI Control Group & $100 \pm 22$ & $\mathrm{I} 42 \pm \mathrm{I} 8$ & $3 I \pm 9$ \\
\hline Normal Control & $104 \pm 4$ & $224 \pm 12$ & $49 \pm 4$ \\
\hline \multicolumn{4}{|l|}{$\begin{array}{l}P \text { values: } \\
\text { SCI-CRF } \\
v .\end{array}$} \\
\hline $\begin{array}{l}\text { SCI-Control } \\
\text { SCI-CRF }\end{array}$ & $<0.05$ & N.S. & $<0.001$ \\
\hline $\begin{array}{l}v . \\
\text { Normal Control } \\
\text { SCI-Control }\end{array}$ & $<0.05$ & $<0.01$ & $<0.001$ \\
\hline Normal Control & N.S. & $<0.00 I$ & $<0.02$ \\
\hline
\end{tabular}


individuals $(49 \pm 4 \mathrm{mg} / \mathrm{dl})$. Since the SCI-CRF patients had marked hypertriglyceridemia, which is known to lower HDL-cholesterol, we compared their HDL-cholesterol levels with these established in hypertriglyceridemic but otherwise normal individuals. HDL-cholesterol in the SCI group was significantly lower $(P<0.00 \mathrm{I})$ than that of the control hypertriglyceridemic individuals $(37 \pm$ $\mathrm{I} \cdot 3 \mathrm{mg} / \mathrm{dl})$.

Within the SCI group with chronic renal failure, no significant difference was found between the dialysed and undialysed patients with respect to the serum lipid fractions studied.

Systolic blood pressure in the study group (I $59 \pm 2 \mathrm{I} \mathrm{mmHg}$ ) was significantly $(P<0.02)$ higher than the control SCI group $(135 \pm 18 \mathrm{mmHg})$. The respective values for diastolic blood pressure ( $82 \pm$ IO and $77 \pm$ I I $\mathrm{mmHg}$ ), however, were not significantly different.

\section{Discussion}

Serum triglyceride level in the SCI patients with chronic renal disease was significantly higher than those found in the SCI patients without renal failure and the age- and sex-matched normal individuals. This observation is consistent with the expected influence of uremia on triglyceride metabolism (Bagdade et al., I968; Brons et al., I972; Daubresse et al., I976; Vaziri et al., I980). Increased synthesis and reduced peripheral clearance of triglycerides associated with the reduced tissue lipoprotein lipase activity have been proposed as possible mechanisms.

In the SCI patients, additional factors such as reduced physical activity, the tubulointerstitial and medullary origin of renal pathology, and proteinuria may also contribute to the genesis of hypertriglyceridemia. Physical exercise has been shown to improve hypertriglyceridemia in patients with renal failure (Goldberg et al., 1979) and those with other conditions (Holloszy et al., 1964; Lopez-s et al., 1974; Erklens et al., 1978). Reduced physical activity due to the associated paralysis and uremia may therefore contribute to hypertriglyceridemia in SCICRF patients.

The underlying renal pathology associated with SCI is chronic obstructive pyelonephritis in which tubulointerstitial and medullary lesions are predominant. Severe hyperlipidemia has been recently reported in analgesic nephropathy which too is primarily tubulointerstitial and medullary in nature (Helber et al., I980). Moreover, the rise in serum triglyceride level after a fat load has been shown to be considerably higher in patients with chronic pyelonephritis than in those with glomerulopathies (Kokot et al., I97I). These observations demonstrate the increased propensity to severe hypertriglyceridemia in patients with advanced renal disease due to tubulointerstitial and medullary damage. Deficiency of a lipidlowering factor(s) associated with renal medulla has been considered to be responsible for this phenomenon (Kokot et al., I97I). Nephrotic syndrome with heavy proteinuria is known to be associated with hyperlipidemia. Only one of our patients (No. 2) had nephrotic range proteinuria ( $>3.0 \mathrm{~g} /$ day). Moreover, the predominant lipid abnormality associated with nephrotic syndrome is hypercholesterolemia which was generally lacking in our patients.

Although no significant difference in serum cholesterol concentration was found between the SCI patients with renal disease and those without renal failure, the values observed in both SCI groups were significantly lower than those established in the sex- and age-matched normal population. The mechanisms of the observed hypocholesterolemia are unclear. Reports on serum cholesterol concen- 
tration in ambulatory dialysis patients are contradictory. Both normal (Losowsky \& Kenward, I968; Brons et al., I972; Ibels et al., I975; Daubresse et al., 1976) and reduced (Brunzell et al., I977; Vaziri et al., I980) levels have been reported previously. Our findings in the SCI-CRF patients are consistent with those of Brunzell et al. (1977) and Vaziri et al. (1980) in ambulatory CRF patients.

Serum HDL-cholesterol in the SCI-CRF patients was significantly lower than those found in the SCI control group, the sex- and age-matched normal individuals and those with hypertriglyceridemia. This finding is suggestive of the possible etiologic role of advanced renal disease in the pathogenesis of reduced HDL-cholesterol observed in our patients. When compared with the values established in the sex- and age-matched normal controls, serum HDLcholesterol was abnormally low in the SCI patients without renal failure. This may be partly a reflection of the lower serum total cholesterol level in these individuals. Physical exercise has been shown to increase HDL-cholesterol both in renal failure patients (Goldberg et al., 1979) and in those with other conditions (Gyntelberg et al., 1977; Erklens et al., 1978). Relative physical inactivity associated with paralysis in SCI patients may therefore contribute to the genesis of their reduced HDL-cholesterol levels.

Low serum levels of HDL-cholesterol have been correlated with an increased incidence of cardiovascular disease in nonuremic man (Miller et al., 1975; Castelli et al., 1977; Gordon et al., 1977). Further studies are necessary to assess the effect of reduced HDL-cholesterol as a risk factor for cardiovascular mortality and morbidity in the SCI patients.

No significant difference was noted in the measured lipid fractions between the dialysed and undialysed SCI-CRF patients. This observation tends to rule against a possible contributory role of hemodialysis in the genesis of lipid disorder in these patients. Due to the small size of the population studied, however, such conclusions cannot be made with certainty.

\section{SUMMARY}

Ten patients with chronic renal failure (CRF) associated with long-standing spinal cord injury (SCI) were studied. A group of age- and sex-matched patients with long-standing SCI but normal renal function were included for comparison. Serum triglycerides were markedly elevated in SCI-CRF patients. Both SCI groups exhibited moderate hypocholesterolemia. High density lipoprotein (HDL)-cholesterol was severely reduced in the SCI-CRF group and moderately reduced in the SCI-control group. Chronic renal failure, reduced physical activity and several other factors may be operative in the genesis of the observed elevated serum triglyceride and reduced HDL-cholesterol levels in this condition.

\section{RÉSUMÉ}

Notre étude porte sur dix patients presentant une défaillance rénal chronique (CRF) associée à une blessure de la colonne vertebrale (SCI) remontant à de nombreuses années. Pour comparer, nous avons inclu un groupe de patients de même âge et sexe ayant une SCI de longue durée, mais avec une fonction rénale normale. Le niveau sérique des triglycérides était considérablement élevé dans le cas des patients souffrant de SCI et de CRF. Les deux groupes exhibaient une hypocholestérolémie modérée. Le niveau de la cholésterine des lipoprotéïnes de haute densité (LHD) etait sévèrement réduit dans le groupe souffrant de SCI et de CRF, et modérément réduit dans le groupe de contrôle avec SCI. La défaillance rénale chronique, l'activité physique reduité et plusieurs autres facteurs encore peuvent être la cause du niveau élevé du sérum des triglycérides et du niveau réduit de LHD dans cette condition. 


\section{ZUSAMMENFASSUNG}

Zehn Patienten mit chronischem Nierenversagen (CRF) im Zusammenhang mit langdauernder Wirbelsäulenverletzung (SCI) wurden untersucht. Zum Vergleich wurde eine Gruppe desselben Alters und Geschlechts mit langdauernder SCI, aber normaler Nierenfunktion in die Untersuchung miteinbezogen. Bei den Patienten mit CRF und SCI waren die Serumtriglyzeridwerte beträchtlich erhöht. Beide Gruppen zeigten mäßige Hypocholesterolämie. Die Lipoproteincholesterine von hoher Dichte (LHD) waren bei der CRF-mit-SCI-Gruppe stark reduziert und bei der SCI-Gruppe mäßig reduziert. Als Ursache der beobachteten erhöhten Serumtriglyzeridwerte und der reduzierten LHDCholesterinwerte in diesen Fällen können CRF, verminderte körperliche Bewegung und mehrere andere Faktoren gelten.

Acknowledgement. The authors would like to thank Chris Byrnes and Norman Penera for gathering the data.

\section{REFERENCES}

Albers, J. J., Wahl, P. W., Cabana, V. C. et al. (1976). Quantitation of apolipoprotein A-I of human plasma high density lipoprotein. Metabolism, 25, 633-644.

BAgDADE, J. D. \& Albers, J. J. (I977). Plasma high density lipoprotein concentrations in chronic hemodialysis and renal transplant patients. N. Engl.F. Med., 296, I436-I 439.

BAgdade, J. D., Casaretto, A. \& Albers, J. (I 976). Effects of chronic uremia, hemodialysis, and renal transplantation on plasma lipids and lipoproteins in man. F. Lab. Clin. Med., 87, 37-48.

Bagdade, J. D., Porte, D., Jr. \& Bierman, E. L. (I968). Hypertriglyceridemia: A metabolic consequence of chronic renal failure. N. Engl. F. Med., 269, I8I-I85.

Bagdade, J. D., Porte, D., Jr., Curtis, F. D. et al. (1968). Uremic lipemia: An unrecognized abnormality in triglyceride synthesis and removal. Trans. Assoc. Am. Phys., 8I, I 90-202.

Bierman, E. L. \& BRUnZell, J. D. (I978). Interrelation of atherosclerosis, abnormal lipid metabolism, and diabetes mellitus. Adv. Mod. Nutr., 2, I87-2 I0.

Brons, M., Christensen, N. C. \& Hordes, M. (1972). Hyperlipoproteinemia in patients with chronic renal failure. Acta Med. Scand., 192, I I9-I23.

Brunzell, J. D., Albers, J. J., Hass, L. B., GoldberG, A. P., Agadoa, L. \& Sherrard, D. (1977). Prevalence of serum lipid abnormalities in chronic hemodialysis. Metabolism, 26, 903-910.

Castelli, W. P., Doyle, J. T., Gordon, T., Hames, C. G., Huortland, M. D., Hulley, S. B., KAGAN, A. \& ZuKEL, W. J. (1977). HDL cholesterol and other lipids in coronary heart disease. The cooperative lipoprotein phenotyping study. Circulation, 55, 767772.

Daubresse, J. C., Lerson, G., Plomteux, G. et al. (1976). Lipids and lipoproteins in chronic uremia: A study of the influence of regular hemodialysis. Eur. F. Clin. Invest. 6, I 59-I66.

Erkiens, D. W., Albers, J. J., Hazzard, W. R., Fredrick, R. C. \& Bierman, E. L. (I978). Moderate exercise increases high density lipoprotein cholesterol in myocardial infarction. Clin. Res., 26, I58A.

Goldberg, A. P., Hagberg, M., Delmez, J. A., Heath, G. W. \& Harter, H. R. (1979). Exercise training improves abnormal lipid and carbohydrate metabolism in hemodialysis patients. Trans. Am. Soc. Artif. Intern. Organs, 25, 43I-436.

Goldstein, J. L., Hazzard, W. R., Schrott, H. G. et al. (I973). Hyperlipidemia in coronary heart disease. I. Lipid levels in 500 survivors of myocardial infarction. F. Clin. Invest., 52, I533-I 543.

Gordon, T., Castelli, W. P., HJortland, M. C., Kannel, W. B. \& Dawber, T. R. (1977). High density lipoprotein as a protective factor against coronary heart disease. The Framingham Study. Am. F. Med., 62, 707-7I4.

Gyntelberg, F., Brennan, R., Holloszy, J. O., Schonfeld, G., Rennie, M. J. \& WeidMAN, S. W. (1977). Plasma triglyceride lowering by exercise despite increased food intake in patients with type IV hyperlipoproteinemia. Am. F. Clin. Nutr., 30, 7 16-725.

Helber, A., Wambach, G., Böttcher, W., Weller, P. \& Schmidt, R. (I980). Hypercholesterolaemia and hypertriglyceridaemia in patients with analgesic nephropathy. Nephron, 26, I I I-II 5 . 
Holloszy, J. O., Skinner, J. S., Toro, G. \& Cureton, T. K. (I964). Effects of a sixmonth program of endurance exercise on the serum lipids of middle-aged men. Am. F. Cardio., 14, 753-760.

Ibels, L. S., Simons, L. A., KING, J. O. et al. (1975). Studies on the nature and causes of hyperlipidaemia in uraemia, maintenance dialysis and renal transplantation. Q.F.Med., 44, 60I-6I4.

Kokot, F., Kuska, J. \& Pakula, E. (I97I). Effect of fat load on serum lipids in patients with renal disease. Nephron, 8, 549-558.

Lewis, L. A., Zuehlke, V., NAKamoto, S. et al. (1966). Renal regulation of serumlipoproteins. N. Engl. F. Med., 275, I097-I IOO.

LindNER, A., CHARRA, B., S HERRARD, D. J., \& SCRIBNER, B. H. (I974). Accelerated atherosclerosis in prolonged maintenance hemodialysis. N. Engl. F. Med., 297, 697-701.

Lopez-s, A., Vial, R., BALART, L. \& ARROYAVE, G. (I974). Effect of exercise and physical fitness on serum lipids and lipoproteins. Atherosclerosis, 20, I-9.

Losowsky, M. S. \& Kenward, D. H. (1968). Lipid metabolism in acute and chronic renal failure. F. Lab. Clin. Med., 71, 736-743.

Lowrie, E. G., Lazarus, J. M., Hampers, C. L. \& Merrill, J. P. (I974). Editorial. Cardiovascular disease in dialysis patients. N. Engl. F. Med., 290, 737-738.

Miller, G. J. \& Miller, N. E. (I975). Plasma-high-density-lipoprotein concentration and development of ischaemic heart disease. Lancet, I, I6-I9.

Vaziri, N. D., Risk, C., Martin, D. \& Novey, H. (I980). Comparison of hyperlipidemia in dialysis patients, renal transplant recipients and steroid treated nonrenal patients. F. Dialysis, 4, 63-7I. 